\title{
Acclimation of juvenile Mugil liza Valenciennes, 1836 (Mugiliformes: Mugilidae) to different environmental salinities
}

\author{
Viviana Lisboa ${ }^{1}$, Indianara F. Barcarolli², Luís A. Sampaio ${ }^{3}$ and Adalto Bianchini ${ }^{2}$
}

Survival and physiological parameters associated with metabolism and osmoregulation were evaluated in juveniles of the Lebranche mullet Mugil liza acclimated to different water salinities (5, 10, 20, 30, and 40\%) for 15 days. Room temperature $\left(25^{\circ} \mathrm{C}\right)$ and photoperiod (12L:12D) were fixed. Fish were fed twice-a-day with commercial diet (28\% crude protein) until satiation. After acclimation, whole body oxygen consumption was measured and fish were euthanized and sampled for blood, gills, and liver. Whole body oxygen consumption and plasma osmolality did not change in the range of salinities tested. The isosmotic point was estimated as $412.7 \mathrm{mOsmol} \mathrm{kg}{ }^{-1}(13.5 \%)$. Gill Na+ $\mathrm{K}^{+}$-ATPase activity tended to be lower at 20 and 30\%, while liver glycogen content was significantly higher at 20\%o than at 5 and $40 \%$. These results indicate that juvenile $M$. liza is able to acclimate for a short-period of time (15 days) to a wide range of salinities (5-40\%). This condition is achieved through adjustments in gill $\mathrm{Na}^{+}, \mathrm{K}^{+}$-ATPase activity and carbohydrate metabolism to regulate plasma osmolality and aerobic/energy metabolism. Therefore, our findings support the idea of catching juveniles M. liza in sea water and rear them in estuarine and marine waters.

A sobrevivência e parâmetros fisiológicos associados ao metabolismo e a osmorregulação foram avaliados em juvenis da tainha Mugil liza aclimatada à diferentes salinidades $\left(5,10,20,30 \mathrm{e} 40 \%\right.$ ) por 15 dias. Foram fixadas a temperatura $\left(25^{\circ} \mathrm{C}\right)$ e o fotoperíodo (12L:12D) da sala onde os experimentos foram realizados. Os peixes foram alimentados duas vezes ao dia com ração comercial ( $28 \%$ de proteína bruta) até a saciedade. Após aclimatação, foi medido o consumo corporal de oxigênio e os peixes foram eutanasiados e foram coletadas amostras de sangue, brânquias e fígado. O consumo corporal de oxigênio e a osmolalidade plasmática não variaram na faixa de salinidade testada. O ponto isosmótico foi estimado em $412,7 \mathrm{mOsmol}$ $\mathrm{kg}^{-1}\left(13,5 \%\right.$ ). A atividade da $\mathrm{Na}^{+}, \mathrm{K}^{+}$-ATPase branquial tendeu a ser menor em 20 e 30\%o, enquanto o conteúdo de glicogênio hepático foi significativamente maior em $20 \%$ do que em 5 e 40\%. Estes resultados indicam que o juvenil de M. liza é capaz de se aclimatar a uma ampla faixa de salinidade (5-40\%) por um curto período de tempo (15 dias). Esta condição é atingida através de ajustes na atividade da $\mathrm{Na}^{+}, \mathrm{K}^{+}$-ATPase branquial e no metabolismo de carboidratos para regular a osmolalidade plasmática e o metabolismo aeróbico/energético. Portanto, nossos achados suportam a ideia de que é possível capturar juvenis da tainha $M$. liza em água do mar e cultivá-los em águas estuarinas e marinhas.

Keywords: Fish, Glycogen, $\mathrm{Na}^{+}, \mathrm{K}^{+}$-ATPase, Osmoregulation, Oxygen consumption.

\section{Introduction}

Aquaculture practices seek to develop a healthy and sustainable environment through the control of biotic and abiotic factors in order to maximize fish growth. Among abiotic factors, the influence of water salinity on fish growth has been reported for several species (Woo \& Kelly, 1995; Sampaio \& Bianchini, 2002; Resley et al., 2006), including the mullet Mugil liza Valenciennes, 1836 (Lisboa et al., 2015).
Euryhaline teleost fish can activate biochemical and physiological mechanisms to face changes in environmental salinity. In low salinities, i.e. below the isosmotic point, they absorb salts $\left(\mathrm{Na}^{+}\right.$and $\left.\mathrm{Cl}^{-}\right)$through the gills to counteract the diffusive loss of ions. In turn, the osmotic gain of water is compensated by production and copious excretion of dilute urine. At higher salinities, i.e. above the isosmotic point, they drink and desalinize sea water at the digestive tract. In this case, water is osmotically absorbed through the intestinal wall and the excess of salts

\footnotetext{
${ }^{1}$ Universidade Federal do Rio Grande (FURG), Instituto de Oceanografia, Programa de Pós-graduação em Oceanografia Biológica, Av. Itália km 8, Campus Carreiros, 96203-900 Rio Grande, RS, Brazil. viviana.lisboa.lisboa@gmail.com

${ }^{2}$ Universidade Federal do Rio Grande (FURG), Instituto de Ciências Biológicas, Av. Itália km 8, Campus Carreiros, $96203-900$ Rio Grande, RS, Brazil. (IFB) barcarolli@gmail.com, (AB) adaltobianchini@furg.br (corresponding author)

${ }^{3}$ Universidade Federal do Rio Grande (FURG), Instituto de Oceanografia, Laboratório de Piscicultura Marinha, Rua do Hotel nº 02, Querência, 96203-900 Rio Grande, RS, Brazil.sampaio@mikrus.com.br
} 
$\left(\mathrm{Na}^{+}\right.$and $\left.\mathrm{Cl}^{-}\right)$is actively secreted at the gills. As a result, a water gain and salt loss is achieved, thus counteracting the obligatory osmotic loss of water and the diffusive gain of salts associated with the osmotic gradient existing between the fish blood and sea water. Using these homeostatic mechanisms, euryhaline teleost fish are able to keep their plasma osmolality more or less constant over a wide range of water salinities (Baldisserotto, 2009). Under steady state, marine teleosts are hyposmotic to sea water, with

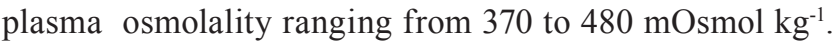
In turn, freshwater teleosts or euryhaline marine teleosts in fresh water have a lower plasma osmolality (260 to 330 mOsmol kg-1), which is still much higher than that found in

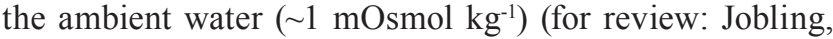
1995; Schmidt-Nielsen, 1996; Evans, 2008).

It is clear from the above that changes in energy consumption are expected to occur associated with fish osmotic regulation over a wide range of environmental salinities. According to Handeland et al. (1998), the osmoregulatory cost is proportional to the osmotic gradient. Therefore, lower energy expenditure would be expected to occur when fish blood plasma is isosmotic with the environmental medium. Indeed, an isosmotic environment has been reported to maximize growth in some euryhaline teleosts, since less energy would be spent in the osmoregulatory process (Woo \& Kelly, 1995; Tsuzuki et al., 2007; Herrera et al., 2009; Nordlie, 2009). This phenomenon will be referred hereafter as the "Isosmotic Theory". According to this theory, the energy spared on osmoregulation can be used for fish growth maximization. However, there is still no consensus about the importance of this energy sparing mechanism in improving fish growth. In fact, the effect of salinity on fish growth will depend on how this environmental parameter affects the standard metabolic rate, food intake, food conversion, and/ or hormonal stimulation (Boeuf \& Payan, 2001), which are shown to be species-specific (Jobling, 1994).

Accurate measurements of the amount of energy spared when fish are maintained at an isosmotic environment are difficult to perform because of the complex interactions existing among the osmoregulatory mechanisms and other physiological processes, which are in turn influenced by environmental factors, as well as the methodology employed. Boeuf \& Payan (2001) reported that the energy spent by fish with osmoregulation can range from $10 \%$ to more than $50 \%$ of the total energy budget.

Plasma osmolality, gill $\mathrm{Na}^{+}, \mathrm{K}^{+}$-ATPase activity, whole body oxygen consumption and liver glycogen content are physiological parameters usually measured to evaluate the effect of salinity in fish (McCormick, 1995; Baldisserotto et al., 2007; Saoud et al., 2007). In fact, $\mathrm{Na}^{+}, \mathrm{K}^{+}$-ATPase is the main enzyme responsible for $\mathrm{NaCl}$ transport across the teleost gills. In freshwater fish, it is associated with salt absorption, while in seawater fish it is related to salt secretion. Therefore, gill $\mathrm{Na}^{+}, \mathrm{K}^{+}$-ATPase activity is usually increased in extreme (low and high) environmental salinities where the osmolality gradient between the fish plasma and ambient salinity is maximized. As a consequence, gill $\mathrm{Na}^{+}, \mathrm{K}^{+}$-ATPase activity is directly related to the maintenance of plasma osmolality homeostasis (Baldisserotto et al., 2007; Evans, 2008).

It is clear from the above that osmoregulation is an energy-demanding process. As previously mentioned, energy spent by fish with osmoregulation can be as high as $50 \%$ of the total energy budget (Boeuf \& Payan, 2001). At this point, it is important to note that glucose is the main source of energy for fish osmoregulation through the oxidative metabolism (Pérez-Robles et al., 2012). In fish, as in other vertebrates, this carbohydrate is mainly stored as glycogen in the liver (Jobling, 1994; Schmidt-Nielsen, 1996). Therefore, measurements of whole body oxygen consumption and liver glycogen content can be good indirect indicators of the energy demand associated with osmoregulation. Theoretically, the optimal environmental salinity for rearing fish would be that showing a combination of lower gradient between ambient osmolality and fish plasma osmolality, where a resulting lower gill $\mathrm{Na}^{+}, \mathrm{K}^{+}$ATPase activity would be observed. In this case, a lower whole body oxygen consumption and higher liver glycogen content would be expected to occur. These conditions would suggest that a likely higher amount of energy could be spared by fish, thus allowing a better growth.

The taxonomic status of Mugilidae from the Caribbean and South American Atlantic coast has been revised. Fish previously identified as $M$. platanus are now correctly identified as the Lebranche mullet M. liza (Menezes et al., 2010). This teleost fish is an important item for estuarine and coastal fisheries in Southern South America (Reis \& D'Incao, 2000). Furthermore, it has being considered for aquaculture in estuarine and marine waters in Brazil. The Lebranche mullet shows a small dietary protein requirement (Carvalho et al., 2010) and occupies a low position in the food web (Oliveira \& Soares, 1996). In the scope of the present study, it is important to mention that the mullet $M$. liza can face very significant changes in environmental osmotic conditions during its life cycle. In South America. It inhabits tropical and subtropical waters from Rio de Janeiro (southeastern Brazil) to Argentina, being especially found at the Patos Lagoon estuary and the adjacent coastal region (Rio Grande do Sul state, southern Brazil) (Vieira et al., 1998). The Lebranche mullet $M$. liza is considered as being an estuarine-dependent fish species (Vieira et al., 1998). As a catadromous fish, mature individuals displace from the estuarine area to the sea for reproduction and spawning. After spawning, its eggs and larvae are transported to the Patos Lagoon estuary, where they develop until reaching sexual maturity. Mature individuals move then to the sea for reproduction and spawning (Vieira et al., 1998). Therefore, juveniles $M$. liza face abrupt, frequent and marked changes in ambient osmolality during its development and growth in the Patos Lagoon estuary (Seeliger et al., 1998). 
Little is known about the effect of environmental parameters on the physiology of juvenile Lebranche mullet. It was shown that growth of juvenile $M$. liza is improved at temperatures between 25 and $30^{\circ} \mathrm{C}$ (Okamoto et al., 2006). Regarding salinity, Sampaio et al. (2002) showed that tolerance of juveniles of the Lebranche mullet to ammonia and nitrite is improved in fish acclimated to intermediate and high salinities respect to those maintained in fresh water. Fonseca Neto \& Spach (1998/1999) reported no mortality after 96 h of abrupt transfer of juvenile $M$. liza from sea water (30\%) to lower salinities $(15,10$ and $5 \%$ ). Very recently, we have shown that salinity influenced growth without significant changes in biochemical parameters (gill $\mathrm{Na}^{+} / \mathrm{K}^{+}$-ATPase and liver glycogen content) in juvenile Lebranch mullet $M$. liza after a 40-days rearing period in different salinities ranging from 0 to $24 \%$ (Lisboa et al., 2015).

The main objective was to evaluate survival and the response of physiological parameters associated with osmoregulation in juveniles of the Lebranche mullet $M$. liza acclimated sea water (30\%), abruptly transferred to a wide range of salinities (5-40\%) and maintained at these salinities for 15 days. Physiological endpoints analyzed included plasma osmolality, gill $\mathrm{Na}^{+}, \mathrm{K}^{+}$-ATPase activity, whole body oxygen consumption, and liver glycogen content. As observed for other euryaline marine teleosts, it is expected that juveniles of the Lebranche mullet $M$. liza would show plasma osmolality varying from 260

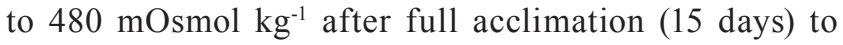
salinity in the range of ambient salinities tested (5-40\%). It is also expected that whole body oxygen consumption and gill $\mathrm{Na}^{+}, \mathrm{K}^{+}$-ATPase activity would be lower in intermediate salinities (10-30\%), while liver glycogen content would be higher under this condition.

\section{Material and Methods}

Fish collection and acclimation. Juvenile $M$. liza were captured at Cassino Beach (Rio Grande, RS, southern Brazil) and transferred to the Laboratory of Marine Fish Culture of the Universidade Federal do Rio Grande (FURG), Rio Grande, RS. Fish acclimation to laboratory conditions was performed in two 1,000-L circular fiber tanks containing sea water at $25^{\circ} \mathrm{C}$ and salinity corresponding to that of the collection site (30\%). Tanks were maintained under natural photoperiod $(12 \mathrm{~h} \mathrm{L:12}$ $\mathrm{h}$ D). Fish were fed twice-a-day (from 10:00 to 11:00 h and from 17:00 to 18:00 h) with a commercial diet $(28 \%$ crude protein) until satiation. Feces produced were siphoned out daily and at least $50 \%$ of the experimental medium was renewed. All procedures used for capture, maintenance and experimentation using juveniles of the Lebranche mullet followed the practices actually recommended by the Brazilian Council for Control of Animal Experimentation (CONCEA).
Experimental design. After acclimation to laboratory conditions for 20 days, 36 fish (wet body weight: $54.1 \pm$ $0.9 \mathrm{~g}$; total length: $17.7 \pm 0.1 \mathrm{~cm})$ were fastened for 24 $\mathrm{h}$, individually weighed (wet body weight; electronic scale; precision: $0.01 \mathrm{~g}$ ) and measured (total length), randomly divided into six groups (6 fish per group). The first group of fish were immediately analyzed for whole body oxygen consumption and had samples collected for plasma osmolality, gill $\mathrm{Na}^{+}, \mathrm{K}^{+}$-ATPase activity and liver glycogen content, as described below. Juvenile mullets from the other 5 groups were kept in sea water $(30 \%$ ) or abruptly transferred to diluted sea water $(5,10$, and $20 \%$ ) or concentrated sea water $(40 \%)$. Sea water at the different experimental salinities was obtained by diluting concentrated sea water ( $40 \%$ salinity) with tap water. In turn, concentrated sea water was obtained by evaporation at $50^{\circ} \mathrm{C}$. Fish were maintained in $300-\mathrm{L}$ circular fiber tanks at the experimental salinities for 15 days. Tanks were provided with a closed circulating system and $80 \%$ of the total water volume was renewed every day. Fish stocking density corresponded to $\sim 1 \mathrm{~g} \mathrm{~L}^{-1}$, as recommended for physiological studies.

The 15-days period of experiment was selected considering that juvenile $M$. liza shows ultrastructural changes in gill chloride cells, which are directly associated with acclimation to fresh and sea water, within few hours or days (4 days) after transfer to a wide range of environmental salinities (Fonseca Neto \& Spach, 1998). Therefore, it would be expected that mullets employed in the present study would be fully acclimated 15 days after the transfer to the experimental salinities tested. In addition, the experimental time employed in the present study (15 days) was already used to acclimate $M$. liza to different salinities for previous physiological (Carvalho et al., 2010) and toxicological (Sampaio et al., 2002) studies.

Water temperature (hand termometer), dissolved oxygen content (oxymeter YSI Model), salinity (refractometer, Atago), $\mathrm{pH}$ ( $\mathrm{pH}$ meter, Quimis), and total ammonia (American Public Health Association (APHA, 2005)) were measured daily. Water samples were also collected over the experimental period for osmolality measurements using a semi-micro osmometer (Knauer, Germany) based on the freezing depression point. Osmolality data were expressed in $\mathrm{mOsm} \mathrm{kg}{ }^{-1}$.

Whole body oxygen consumption. At the end of the experimental period, whole body oxygen consumption was measured following the procedures described by Cunha et al. (2009). Fish were fastened for $24 \mathrm{~h}$ prior to oxygen consumption measurements. Water aeration was removed and the tank was completely sealed with a transparent plastic sheet to avoid any air diffusion. Dissolved oxygen content in the water was recorded every $15 \mathrm{~min}$ for up to 1 h. Measurements were performed in triplicate for each tank using an oximeter (YSI model Hexis 55). They were never performed when the water saturation level with oxygen 
dropped to $70 \%$ of its maximum to avoid a possible effect of this water parameter on fish oxygen consumption. The rate of oxygen consumption $(O C)$ was calculated using the following equation:

$$
\left.O C=\left(O_{i}-O_{f}\right) x V\right) / T x B
$$

where $O_{i}$ and $O_{f}$ correspond to the initial and final dissolved oxygen content in the water $\left(\mathrm{mg} \mathrm{O}_{2} \mathrm{~L}^{-1}\right)$, respectively, $V$ is the tank volume (L), $B$ is the fish biomass $(\mathrm{g})$, and $T$ is the measurement duration (h). Results were expressed in $\mathrm{mg}$ $\mathrm{O}_{2}$ g wet body mass $^{-1} \mathrm{~h}^{-1}$.

Tissue collection and analysis. After the oxygen consumption measurement, fish were anesthetized (50 ppm benzocain) and blood samples were collected by heart puncture using 1-mL heparinized disposable syringes and centrifuged. Plasma obtained was collected and stored in ultrafreezer $\left(-80^{\circ} \mathrm{C}\right)$ for further osmolality measurement, as described below. The second gill arch at the left side of the gill chamber and the liver were dissected, immediately frozen in liquid nitrogen and stored in ultrafreezer $\left(-80^{\circ} \mathrm{C}\right)$ for further measurement of gill $\mathrm{Na}^{+}, \mathrm{K}^{+}$-ATPase activity and liver glycogen content, respectively, as described below.

Fish plasma osmolality was determined using the semimicro osmometer (Knauer, Germany) based on the freezing depression point. The fish isosmotic point was assessed by considering the intersection of the isosmotic line with the regression line estimated between plasma and water osmolality as described by Sampaio \& Bianchini (2002). Results were expressed in mOsm $\mathrm{kg}^{-1}$.

Gill samples were homogenized with $300 \mu \mathrm{l}$ of a buffer solution ( $\mathrm{pH}$ 7.3) containing $150 \mathrm{mM}$ sucrose, 10 $\mathrm{mM}$ ethylenediaminetetraacetic acid, $50 \mathrm{mM}$ imidazole, and $11.5 \mathrm{mM}$ sodium deoxycholate, and centrifuged at $10,000 \mathrm{~g}$ for $30 \mathrm{~min}\left(4^{\circ} \mathrm{C}\right)$. The supernatant was used for $\mathrm{Na}^{+}, \mathrm{K}^{+}$-ATPase activity determination at $25^{\circ} \mathrm{C}$, following procedures described by McCormick (1993). Sample absorbance was measured using a spectrophotometer (ELX 800 Universal Microplate Reader/Bio-Teck Instruments, Winooski, Vermont, USA). The protein concentration in the supernatant was determined using a commercial reagent kit based on the Biuret reagent (Doles, Goiânia, GO, Brazil). Enzyme activity was expressed in $\mu$ moles ADP mg protein ${ }^{-1} \mathrm{~h}^{-1}$.

Liver samples were weighed and homogenized in 100 $\mathrm{mM}$ sodium citrate solution ( $10 \%$ weight/volume). Liver glycogen content was determined using an adaptation of the method of Carr \& Neff (1984). In this case, the homogenized sample was split into two aliquots. All glycogen present in one aliquot of each sample was enzymatic converted into glucose using $\alpha$-amiloglucosidase. Glucose concentration was then analyzed in the two aliquots of each sample using a commercial reagent kit based on the glucose-oxidase method (Doles, Goiânia, GO, Brazil). Sample absorbance was measured using the spectrophotometer (ELX 800
Universal Microplate Reader/Bio-Teck Instruments, Winooski, Vermont, USA). Glycogen concentration was calculated considering the difference in glucose concentration between the aliquots digested and nondigested with the enzyme. Results were expressed in $\mathrm{mg}$ g wet tissue ${ }^{-1}$.

Data presentation and analysis. Results were expressed as mean \pm standard error $(n=6)$. For all parameters analyzed, significant differences among salinities were assessed by One-Way analysis of variance (ANOVA) followed by the Tukey's test. For each salinity, comparison of mean values between water and plasma osmolality was performed using the non-paired Student $t$-test. Water and plasma osmolality data were subjected to linear regression analysis. Gill $\mathrm{Na}^{+}, \mathrm{K}^{+}$-ATPase activity and liver glycogen content data were subjected to non-linear regression analysis (polynomial, quadratic). For all analyses, the level of significance adopted was $95 \%(\alpha=0.05)$.

\section{Results}

Water osmolality was significantly different among the experimental salinities (Table 1). Dissolved oxygen content, temperature and ammonia concentration $\left(\mathrm{NH}_{3}-\mathrm{N}\right)$ in the water did not change throughout the experimental period and among treatments $(P>0.05)$. Therefore, a general mean value was calculated for dissolved oxygen content $\left(6.34 \pm 0.18 \mathrm{mg} \mathrm{O}_{2} \mathrm{~L}^{-1}\right)$, temperature $\left(24.0 \pm 0.20^{\circ} \mathrm{C}\right)$ and ammonia concentration $\left(0.03 \pm 0.00 \mathrm{NH}_{3}-\mathrm{N}\right)$. However, water $\mathrm{pH}$ increased significantly $(P<0.05)$ from $7.70 \pm$ 0.06 at the lowest salinity $(5 \%)$ to $8.02 \pm 0.06$ at the highest salinity (40\%).

No fish mortality was observed over the whole experimental period. Mean whole body oxygen consumption of juvenile mullets before transference to the experimental salinity (time 0 ) was $0.34 \pm 0.03 \mathrm{mg} \mathrm{O}_{2} \mathrm{~g}^{-1} \mathrm{~h}^{-1}$. No significant change was observed in whole body oxygen consumption in the range of salinities tested (Table 1).

Table 1. Water osmolality, plasma osmolality and whole body oxygen consumption of juveniles of the Lebranche mullet Mugil liza maintained in different salinities for 15 days. Data are expressed as mean \pm standard error $(n=6)$. Different letters indicate significant different mean values among salinities for each parameter analyzed $(P<0.05)$.* indicates significant difference between water and plasma osmolality for each experimental salinity $(P<0.05)$.

\begin{tabular}{crrr}
\hline $\begin{array}{c}\text { Salinity } \\
(\%)\end{array}$ & $\begin{array}{r}\text { Water osmolality } \\
\left(\mathrm{mOsm} \mathrm{kg}^{-1}\right)\end{array}$ & $\begin{array}{r}\text { Plasma osmolality } \\
\left.(\mathrm{mOsm} \mathrm{kg})^{-1}\right)\end{array}$ & $\begin{array}{r}\text { Oxygen consumption } \\
\left(\mathrm{mg} \mathrm{O}_{2} \mathrm{~g}^{-1} \mathrm{~h}^{-1}\right)\end{array}$ \\
\hline 5 & $168 \pm 3.1^{\mathrm{a}}$ & $473.4 \pm 41.4^{\mathrm{a}^{*}}$ & $0.36 \pm 0.08^{\mathrm{a}}$ \\
10 & $332 \pm 4.7^{\mathrm{b}}$ & $330.0 \pm 41.0^{\mathrm{a}}$ & $0.43 \pm 0.03^{\mathrm{a}}$ \\
20 & $565 \pm 2.5^{\mathrm{c}}$ & $401.5 \pm 11.8^{\mathrm{a}^{*}}$ & $0.38 \pm 0.07^{\mathrm{a}}$ \\
30 & $910 \pm 5.2^{\mathrm{d}}$ & $467.4 \pm 35.8^{\mathrm{a}^{*}}$ & $0.32 \pm 0.05^{\mathrm{a}}$ \\
40 & $1080 \pm 3.5^{\mathrm{e}}$ & $414.4 \pm 54.5^{\mathrm{a}^{*}}$ & $0.36 \pm 0.07^{\mathrm{a}}$ \\
\hline
\end{tabular}


Mean plasma osmolality of juvenile mullets before transference to the experimental salinities (time 0) corresponded to $422.0 \pm 17.0 \mathrm{mOsmol} \mathrm{kg}{ }^{-1}$. As observed for oxygen consumption, plasma osmotic concentration did not change among water salinities. However, a significant difference was observed between plasma and water osmolality in all salinities tested, except at $10 \%$. Plasma osmolality was higher than water osmolality in fish maintained at 5\% and lower than water osmolality in fish kept at 20, 30 and 40\% (Table 1). The slope value of the regression line between plasma and water osmolality was not significant $(b=0.023 ; P>0.05)$. The isosmotic point of juveniles of the Lebranche mullet was estimated as 412.7 mOsmol kg-1 , which corresponded to $13.5 \%$ (Fig. 1).

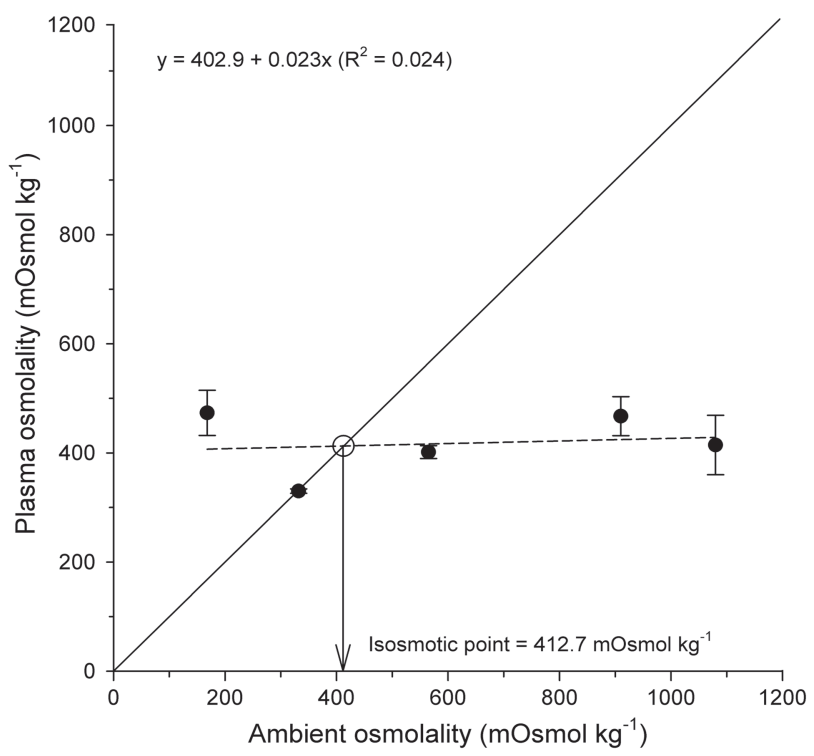

Fig. 1. Plasma osmolality in juveniles of the Lebranche mullet Mugil liza as a function of ambient water osmolality. Values are expressed as mean \pm standard error $(n=6)$. Data were fitted using a linear regression analysis $(y=a+b x)$. The straight line corresponds to the isosmotic line while the arrow indicates the isosmotic point.

Mean gill $\mathrm{Na}^{+}, \mathrm{K}^{+}$-ATPase activity of juvenile mullets before transference to the experimental salinities (time 0 ) corresponded to $0.81 \pm 0.22 \mu$ moles ADP mg protein ${ }^{-1} \mathrm{~h}^{-1}$. Enzyme activity was not significantly affected by salinity, but tended to be lower at intermediate salinities (20 and $30 \%$ ) and higher at extreme salinities (5 and 40\%). When taken together, mean values followed an inverse polynomial quadratic function (Fig. 2).

Mean liver glycogen content of juvenile mullets before transference to the experimental salinities (time 0 ) was $0.22 \pm$ $0.03 \mathrm{mg} \mathrm{g}^{-1}$. In contrast to the other parameters analyzed, liver glycogen content was significantly affected by salinity. It was significantly higher in fish maintained at $20 \%$ o than in those maintained at 5 or $40 \%$, but similar to those at 10 and $30 \%$. When taken together, mean values of liver glycogen content followed a direct polynomial quadratic function (Fig. 3).

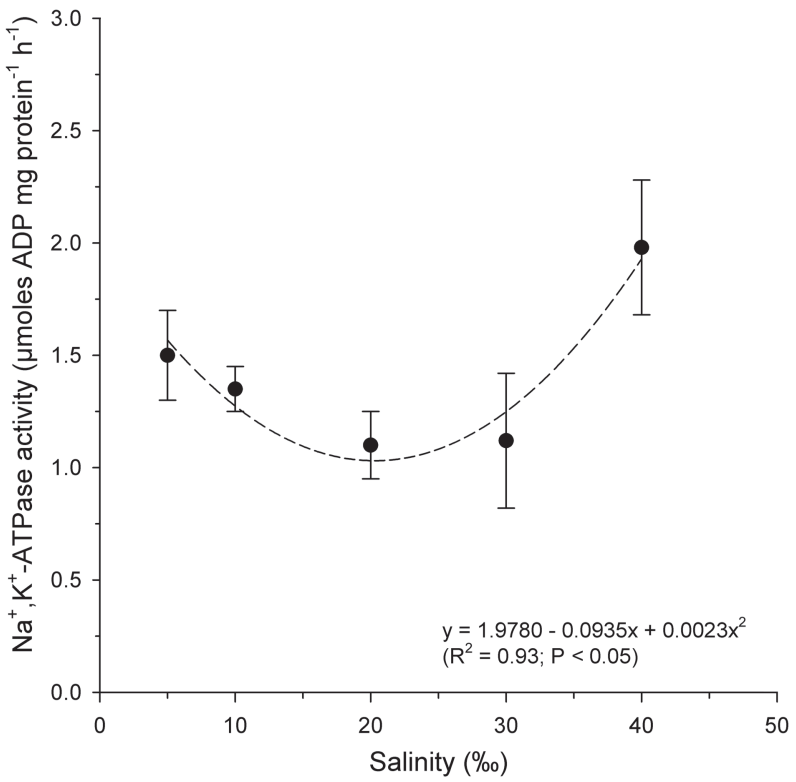

Fig. 2. Gill $\mathrm{Na}^{+}, \mathrm{K}^{+}$-ATPase activity in juveniles of the Lebranche mullet Mugil liza maintained at different salinities for 15 days. Values are expressed as mean \pm standard error ( $\mathrm{n}$ $=6$ ). Data were fitted using a non-linear regression analysis (polynomial; quadratic).

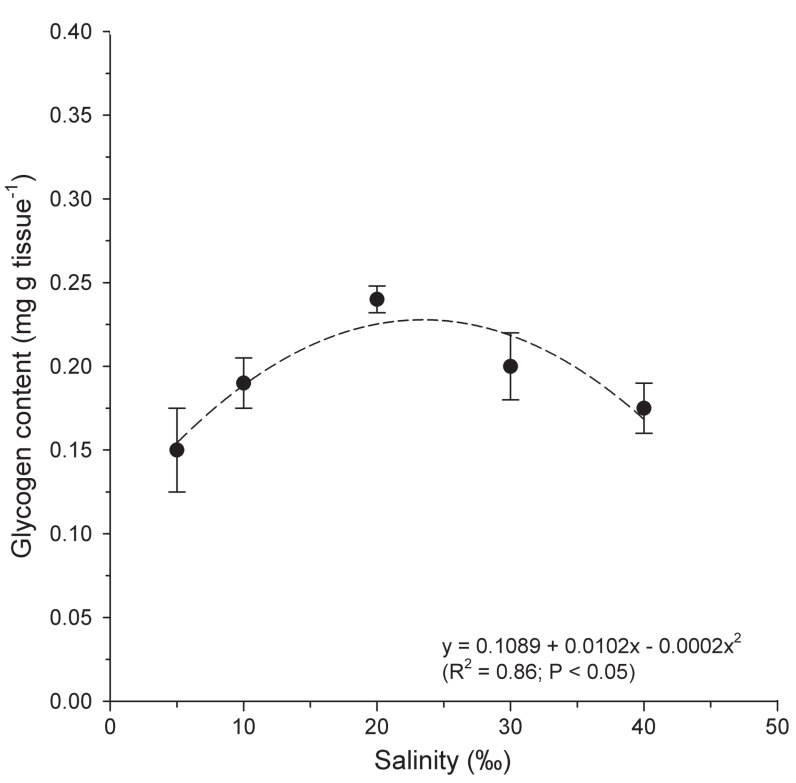

Fig. 3. Liver glycogen content in juveniles of the Lebranche mullet Mugil liza maintained at different salinities for 15 days. Values are expressed as mean \pm standard error $(\mathrm{n}=$ 6). Data were fitted using non-linear regression analysis (polynomial; quadratic).

\section{Discussion}

Juveniles of the Lebranche mullet Mugil liza are naturally subjected to important changes in environmental salinity over its life cycle. An adequate ability to cope with these changes is imperative for M. liza to complete its life cycle. 
This ability was clearly observed in juvenile $M$. liza exposed to a wide range of salinities. This statement is based on the following facts: (1) juvenile mullets tested in the present study were able to survive after abrupt transfer from sea water $(30 \%)$ to a wide range of experimental salinities $(5-40 \%)$; (2) no significant change in plasma osmolality was observed after acclimation of juvenile mullets to the different environmental salinities, and (3) the slope of the regression line between plasma and water osmolality was not significant $(b=0.023)$, indicating a strong capacity of juvenile mullets to regulate plasma osmolality in a wide range of water salinities.

The well-developed osmoregulatory capability showed by juvenile $M$. liza tested in the present study $(18 \mathrm{~cm}$ body length) combined with the fact that juvenile $M$. liza smaller than 2.8-3.3 cm are not able to tolerate abrupt transfer from sea water $(30 \%)$ to fresh water (Fonseca Neto \& Spach, 1998/1999) suggests that juveniles of the Lebranche mullet have already fully developed their osmoregulatory ability. In fact, changes in this ability are shown to occur over the ontogenetic development of other fish species such as the fat snook Centropomus parallelus (Tsuzuki et al., 2007) and the Brazilian flounder Paralichthys orbignyanus (Sampaio et al., 2007). Unfortunately, there is no report describing the ontogenesis of osmoregulation in the Lebranche mullet $M$. liza. Full osmoregulatory capability of the stripped mullet M. cephalus is reached when individuals achieve 4.0-6.9 $\mathrm{cm}$ body length (Nordlie et al., 1982), a range of body sizes lower than the mean body size of juveniles of the Lebranche mullet $M$. liza analyzed here (18 $\mathrm{cm}$ body length).

No significant effect of environmental salinity on plasma osmolality was observed in juveniles of the Lebranche mullet $M$. liza. However, a slightly positive but not significant correlation (linear regression; $\mathrm{b}=0.023 ; P$ $>0.05$ ) between environmental and plasma osmolality was observed. This fact could be associated with a possible dehydration suffered by fish when exposed to hyperosmotic environments (Sampaio \& Bianchini, 2002; Resley et al., 2006; Saoud et al., 2007). In fact, plasma osmolality in juveniles of the Lebranche mullet $M$. liza maintained at 5\% (mean value: $473.4 \pm 41.4 \mathrm{mOsmol} \mathrm{kg}^{-1}$ ) or $30 \%$ (mean value: $467.4 \pm 35.8 \mathrm{mOsmol} \mathrm{\textrm {kg } ^ { - 1 }}$ ) was higher than that reported for diadromous fish acclimated to fresh water $(310.0 \pm 6.5$ mOsmol $\left.\mathrm{kg}^{-1}\right)$ or sea water $\left(402.6 \pm 20.4 \mathrm{mOsmol} \mathrm{\textrm {kg } ^ { - 1 }}\right)$, including the stripped mullet $M$. cephalus (fresh water: $326.7 \mathrm{mOsmol} \mathrm{kg}$; ; sea water: $356.7 \mathrm{mOsmol} \mathrm{kg}{ }^{-1}$ ) (Nordlie et al., 1982; Nordlie, 2009).

The isosmotic point for juveniles of the Lebranche mullet was estimated as $412.7 \mathrm{mOsmol} \mathrm{kg}^{-1}$, which corresponded to $13.5 \%$. In this case, fish is hyper-regulating above this environmental salinity and hypo-regulating above it. According to the idea that energy consumption would be reduced at the isosmotic condition, a lower gill $\mathrm{Na}^{+}, \mathrm{K}^{+}$-ATPase activity and oxygen consumption would be expected in water salinities close to the isosmotic point. Reduced energy consumption, indirectly indicated in the present study by higher liver glycogen content, would be also expected in water salinities close to that where fish is isosmotic respect to the environment. However, whole body oxygen consumption and gill $\mathrm{Na}^{+}, \mathrm{K}^{+}$-ATPase activity of juveniles of the Lebranche mullet did no change significantly among water salinities. Moreover, despite the fact that the gill $\mathrm{Na}^{+}, \mathrm{K}^{+}$-ATPase activity and liver glycogen content followed a U-shape curve according to the water salinity, the lower mean values of enzyme activity were observed at 20 and $30 \%$ and the higher mean value of liver glycogen content was found at $20 \%$. Also, it is important to note that juveniles of $M$. liza reared at $24 \%$ were shown to grow better than those maintained in fresh water for 40 days. However, fish reared at $12 \%$, which is very close to its isosmotic point $(13.5 \%)$, showed similar growth to those maintained at 0, 6 and 24\%o (Lisboa et al., 2015). Taken together, these findings clearly do not support the "Isosmotic Theory" for juveniles of the Lebranche mullet M. liza.

Regarding gill $\mathrm{Na}^{+}, \mathrm{K}^{+}$-ATPase activity, our data are in contrast to those reported for juveniles of the coho salmon Oncorhynchus kisutch (Morgan \& Iwama, 1998) and gilthead sea bream Sparus aurata (Laiz-Carrión et al., 2005). In these fish species, gill enzyme activity also followed a U-shape pattern with the environmental salinity, but the lowest value was found in water salinity close to the isosmotic point. Nevertheless, our results are in agreement with those reported for the rabbitfish Siganus rivulatus, where enzyme activity also followed a U-shape pattern across a wide range of water salinities with the lower values being observed in water salinities not close to that corresponding to the isosmotic point (14.6\%) (Saoud et al., 2007). Furthermore, it was shown that gill $\mathrm{Na}^{+}, \mathrm{K}^{+}-$ ATPase activity in the milkefish Chanos chanos did not show a clear pattern of change across salinities, with the lower enzyme activity value being found at $35 \%$. Actually, Morgan \& Iwama (1998) have suggested that the response of the gill $\mathrm{Na}^{+}, \mathrm{K}^{+}$-ATPase activity to environmental salinity may be species-dependent, which could explain the great variability observed among euryhaline fish species.

The U-shape curve displayed by the gill $\mathrm{Na}^{+}, \mathrm{K}^{+}$-ATPase activity in $M$. liza according to the water salinity combined with the observed lack of change in plasma osmolality is indicative that enzyme activity was stimulated at the extreme salinities (5 and 40\%o). Under these conditions, the higher $\mathrm{Na}^{+}, \mathrm{K}^{+}$-ATPase activity would be a positive response to compensate the higher loss and gain of $\mathrm{NaCl}$ occurring at 5 and $40 \%$, respectively. In fact, increased changes in $\mathrm{NaCl}$ fluxes across the gills would be a consequence of the higher osmotic gradient existing between the ambient osmolality and fish plasma osmolality at 5 and 40\%. In this case, a higher gill $\mathrm{Na}^{+}, \mathrm{K}^{+}$-ATPase activity would increase the absorption and secretion of $\mathrm{NaCl}$ in fish at 5 and $40 \%$, respectively. Gill enzyme activity is described to be regulated by neurochemical and/or endocrine mediators released after stimulation by different triggers, including external salinity and blood osmolality (Evans, 2008). 
Despite the gill $\mathrm{Na}^{+}, \mathrm{K}^{+}$-ATPase activity in $M$. liza followed a U-shape curve according to the water salinity, no significant difference was observed among the experimental salinities. This finding is in complete agreement with previous studies on the effect of salinity on the ultrastructural changes in gills of $M$. liza after acclimation to different salinities. Fonseca Neto \& Spach (1998) reported that significant ultrastructural changes in chloride cells are only observed in M. liza subjected to salinities lower than 3\%o. Furthermore, they showed that no significant difference was observed among mullets subjected to salinities ranging from 5 to $34 \%$, a similar range of salinities used in the present study.

In contrast to our findings, oxygen consumption in $M$. cephalus acclimated for 8 days in laboratory augmented with increasing water salinity (Nordlie \& Leffler, 1975). In turn, the oxygen consumption changes observed in the present study with the juvenile $M$. liza acclimated for 15 days to different environmental salinities correspond to the Type 4 response described by Kinne (1967). Similar to our findings, Morgan \& Iwama (1998) reported that water salinity did not influence oxygen consumption in juvenile coho salmon. Therefore, it seems that 15 days is a suitable period of time to acclimate juveniles of the Lebranche $M$. liza to different environmental salinities without changes in the aerobic metabolism.

Osmoregulation is an energy demanding activity and is fuelled mainly by glucose (Pérez-Robles et al., 2012). This carbohydrate is an important source that provides energy for animal metabolism and an increased plasma concentration of this metabolite after osmotic stress has been reported for several fish species (Herrera et al., 2009). Depending on stress intensity and duration, the plasma glucose level can be sustained through glycogenolysis (Baldisserotto et al., 2007), which is a known secondary response to stress. The liver glycogen concentration in juveniles of the Lebranche mullet was significantly lower at the extreme salinities ( 0 and $40 \%$ ) than at $20 \%$. This finding is in complete agreement with that observed for gill $\mathrm{Na}^{+}, \mathrm{K}^{+}$-ATPase activity, suggesting that the energy demand to regulate the plasma osmotic concentration in extreme conditions was likely provided through glucose oxidation. In this case, a higher glycogen mobilization from liver would occur, thus leading to the observed lower glycogen content in the liver.

Finally, many authors have discussed on the advantages of keeping fish under isosmotic conditions. This practice would imply that the energy saved in the absence of an important osmotic work could maximize fish growth (Boeuf \& Payan, 2001; Saoud et al., 2007; Tsuzuki et al., 2007). However, this theory seems to be species-specific, since it has been proved for some fish species like Sparus sarba (Woo \& Kelly, 1995), but not for others like Paralichthys orbignyanus (Sampaio \& Bianchini, 2002). Very recently, we have shown that juveniles of the Lebranche mullet $M$. liza reared at $12 \%$, a salinity close to the isosmotic point, did not display a better growth than those cultivated in a wide range of salinities (0-24\%) (Lisboa et al., 2015). Results from the present study are in agreement with this finding, thus suggesting that the idea of improving fish growth at isosmotic condition cannot be considered for juveniles of the Lebranche mullet M. liza. However, it is important to note that the present findings clearly indicate that juveniles of M. liza is able to keep its plasma osmotic homeostasis after 15 days of acclimation to a wide range of salinities through adequate adjustments in gill $\mathrm{Na}^{+}, \mathrm{K}^{+}-$ ATPase and liver glycogen metabolism, without significant changes in the aerobic metabolism. This would suggest that juvenile mullets could be captured in sea water and abruptly transferred and reared in estuarine waters.

\section{Acknowledgments}

Viviana Lisboa was a PhD fellowship from the Conselho Nacional de Desenvolvimento Científico e Tecnológico (CNPq), Brasília, DF, Brazil. Luís A. Sampaio and Adalto Bianchini are research fellows from the Brazilian CNPq. Adalto Bianchini is also supported by the International Canadian Research Chair Program International Development Research Centre (IDRC), Ottawa, Canada.

\section{References}

American Public Health Association (APHA). 2005. Standard methods for the examination of water and wastewater. $21^{\text {th }}$ ed. Washington, D.C., APHA. 1v.

Baldisserotto, B. 2009. Fisiologia de peixes aplicada à Piscicultura. 2. ed., Santa Maria, Ed. da UFSM, 349p.

Baldisserotto, B., J. M. M. Romero \& B. G. Kapoor. 2007 (Eds.). Fish osmoregulation. Enfield, Science Publishers, 527p.

Boeuf, G. \& P. Payan. 2001. How should salinity influence fish growth? Comparative Biochemistry and Physiology Part C, 130: 411-423.

Carr, R. S. \& J. M. Neff. 1984. Quantitative semi-automated enzymatic assay for tissue glycogen. Comparative Biochemistry and Physiology, 77B: 447-449.

Carvalho, C. V. A., A. Bianchini, M. B. Tesser \& L. A. Sampaio. 2010. The effect of protein levels on growth, postprandial excretion and tryptic activity of juvenile mullet Mugil platanus (Gunther). Aquaculture Research, 41: 511-518.

Cunha, V. L., R. V. Rodrigues, M. H. Okamoto \& L. A. Sampaio. 2009. Consumo de oxigênio pós-prandial de juvenis do pampo Trachinotus marginatus. Ciência Rural, Santa Maria, 39: $1257-1259$.

Evans, D. H. 2008. Teleost fish osmoregulation: what have we learned since August Krogh, Homer Smith, and Ancel Keys. American Journal of Physiology. Regulatory and Integrative Comparative Physiology, 295: R704-R713.

Fonseca Neto, J. C \& H. L. Spach. 1998. Effect of environmental salinity on the apical surface of chloride cells of the euryhaline teleost Mugil platanus (Pisces, Mugilidae). Iheringia, Série Zoologia, 85: 151-156.

Fonseca Neto, J. C. \& H. L. Spach. 1998/1999. Sobrevivência de juvenis de Mugil platanus Günther, 1880 (Pisces, Mugilidae) em diferentes salinidades. Boletim do Instituto de Pesca, 25: $13-17$. 
Handeland, S. O., A. Berge, B. Th. Björnsson \& S. O. Stefansson. 1998. Effect of temperature and salinity on osmoregulation and growth of Atlantic salmon (Salmo salar L.) smolts in seawater. Aquaculture, 168: 289-302.

Herrera, M., L. Vargas-Chacoff, I. Hachero, I. Ruíz-Jarabo, A. Rodiles, J. I. Navas \& J. M. Mancera. 2009. Osmoregulatory changes in wedge sole (Dicologoglossa cuneata Moreau, 1881) after acclimation to different environmental salinities. Aquaculture Research, 40: 762-771.

Jobling, M. 1994. Fish bioenergetics. $1^{\text {st }}$ ed. London, Chapman \& Hall, 309p. (Fish and fisheries series, 13).

Jobling, M. 1995. Environmental biology of fishes. $1^{\text {st }}$ ed. London, Chapman \& Hall, 455p. (Fish and fisheries series, 16).

Kinne, O. 1967. Physiology of estuarine organisms with special reference to salinity and temperature: General aspects. No. 83, Pp. 525-540. In: Lauff, G. H. (Ed.). Estuaries. Washington, American Association for the Advancement of Science Publication.

Laiz-Carrión, R., S. Sangiao-Alvarellos, J. M. Guzmán, M. P. M. Río, J. L. Soengas \& J. M. Mancera. 2005. Growth performance of gilthead sea bream Sparus aurata in different osmotic conditions: implications for osmoregulation and energy metabolism. Aquaculture, 250: 849-861.

Lisboa, V., I. F. Barcarolli, L. A. Sampaio \& A. Bianchini. 2015. Effect of salinity on survival, growth and biochemical parameters in juvenile Lebranch mullet Mugil liza. Neotropical Ichthyology, 13: 447-452.

McCormick, S. D. 1993. Methods for non lethal gill biopsy and measurement of $\mathrm{Na}^{+}, \mathrm{K}^{+}$-ATPase activity. Canadian Journal of Fisheries and Aquatic Sciences, 50: 656-658.

McCormick, S. D. 1995. Hormonal control of gill Na+, $\mathrm{K}^{+}$-ATPase and chloride cell function. Pp. 285-315. In: Wood, C. M. \& T. J. Shuttleworth (Eds.). Cellular and molecular approaches to fish regulation. $1^{\text {st }}$ ed. San Diego, Academic Press.

Menezes, N. A., C. Oliveira \& M. Nirchio. 2010. An old taxonomic dilemma: the identity of the western south Atlantic lebranche mullet (Teleostei: Perciformes: Mugilidae). Zootaxa, 2519: 59-68.

Morgan, J. D. \& G. K. Iwama. 1998. Salinity effects on oxygen consumption, gill $\mathrm{Na}^{+}, \mathrm{K}^{+}$- ATPase and ion regulation in juvenile coho salmon. Journal of Fish Biology, 53: 1110-1119.

Nordlie, F.G. 2009. Environmental influences on regulation of blood plasmaserum components in teleost fish: a review. Reviews in Fish Biology and Fisheries, 19: 481-564.

Nordlie, F. G. \& C. W. Leffler. 1975. Ionic regulation and the energetics of osmoregulation in Mugil cephalus Lin. Comparative Biochemistry and Physiology, 51A: 125-131.

Nordlie, F. G., W. A. Szelistowski, W. C. Nordlie. 1982. Ontogenesis of osmotic regulation in the striped mullet, Mugil cephalus L. Journal of Fish Biology, 20: 79-86.

Okamoto, M. H., L. A. Sampaio \& A. P. Maçada. 2006. Efeito da temperatura sobre o crescimento e a sobrevivência de juvenis da tainha Mugil platanus Günther, 1880. Atlântica, Rio Grande, 28: 61-66.

Oliveira, I. R. \& L. S. H. Soares. 1996. Alimentação da tainha Mugil platanus Günther, 1880) (Pisces: Mugilidae), da região estuarino-lagunar de Cananéia, São Paulo, Brasil. Boletim do Instituto de Pesca, 23: 95-104.
Pérez-Robles, J., A. D. Re, I. Giffard-Mena \& F. Díaz. 2012. Interactive effects of salinity on oxygen consumption, ammonium excretion, osmoregulation and $\mathrm{Na}^{+} / \mathrm{K}^{+}$-ATPase expression in the bullseye puffer (Sphoeroides annulatus, Jenyns 1842). Aquaculture Research, 43: 1372-1383.

Reis, E. G. \& F. D'Incao. 2000. The present status of artisanal fisheries of extreme Southern Brazil: an effort towards community-based management. Ocean \& Coastal Management, 43: 585-595.

Resley, M. J., K. A. Webb Jr. \& G. J. Holt. 2006. Growth and survival of juvenile cobia, Rachycentron canadum, at different salinities in recirculating aquaculture system. Aquaculture, 253: 398-407.

Sampaio, L. A. \& A. Bianchini. 2002. Salinity effects on osmoregulation and growth of the euryhaline flounder Paralichthys orbignyanus. Journal of Experimental Marine Biology and Ecology, 269: 187-196.

Sampaio, L. A., L. S. Freitas, M. H. Okamoto, L. R. Louzada, R. V. Rodrigues \& R. B. Robaldo. 2007. Effects of salinity on Brazilian flounder Paralichthys orbignyanus from fertilization to juvenile settlement. Aquaculture, 262: 340346.

Sampaio, L. A., W. Wasielesky, K. C. Miranda-Filho. 2002. Effect of salinity on acute toxicity of ammonia and nitrite to juvenile Mugil platanus. Bulletin of Environmental Contamination and Toxicology, 68: 668-674.

Saoud, I. P., S. Kreydiyyeh, A. Chalfoun \& M. Fakih. 2007. Influence of salinity on survival, growth, plasma osmolality and gill $\mathrm{Na}^{+-} \mathrm{K}^{+}$-ATPase activity in the rabbitfish Siganus rivulatus. Journal of Experimental Marine Biology and Ecology, 348: 183-190.

Schmidt-Nielsen, K. 1996. Fisiologia animal: adaptação e meio ambiente. São Paulo, Ed. Santos, 611p. Título original: Animal physiology: adaptation and environment.

Seeliger, U., C. Odebrecht \& J. P. Castello (Eds.). 1998. Os ecossistemas costeiro e marinho do extremo Sul do Brasil. Rio Grande, Ed. Ecoscientia, 326p.

Tsuzuki, M. Y., J. K. Sugai, J. C. Maciel, C. J. Francisco \& V. R. Cerqueira. 2007. Survival, growth and digestive enzyme activity of juveniles of the fat snook (Centropomus parallelus) reared at different salinities. Aquaculture, 271: 319-325.

Vieira, J. P., J. P. Castello \& L. E. Pereira. 1998. Ictiofauna. Pp. 60-68. In: Seeliger, U., C. Odebrecht \& J. P. Castello (Eds.). Os ecossistemas costeiro e marinho do extremo Sul do Brasil. Rio Grande, Ed. Ecoscientia.

Woo, N. Y. S. \& S. P. Kelly. 1995. Effects of salinity and nutritional status on growth and metabolism of Sparus sarba in a closed seawater system. Aquaculture, 135: 229-238.

Submitted August 25, 2014 Accepted April 04, 2015 by Bernardo Baldisserotto Published September 25, 2015 